\title{
Correction to: Ultrasonic Characterization of Thermally Sprayed Coatings
}

\author{
Safia Lemlikchi ${ }^{1} \cdot$ Jesper Martinsson $^{2} \cdot$ Ahmed Hamrit $^{3} \cdot$ Hakim Djelouah $^{4}$.
} Mohammed Asmani $^{5} \cdot$ Johan Carlson $^{2}$

Published online: 4 February 2019

(C) ASM International 2019

\section{Correction to:}

\author{
J Therm Spray Tech \\ https://doi.org/10.1007/s11666-019-00832-w
}

The first name of author Ahmed Hamrit was misspelled as

"Ahmet" in the original article. Please note that the correct spelling of his name is "Ahmed" as shown in this correction.

The original article can be found online at https:// doi.org/10.1007/s11666-019-00832-w.

\section{Safia Lemlikchi}

slemlikchi@cdta.dz

1 Division milieu ionisés et lasers, Centre de Developpement des Technologies Avancees, Algiers, Algeria

2 Luleå University of Technology, Luleå, Sweden

3 ALGESCO, Blida, Algeria

4 Université des Sciences et de la Technologie Houari Boumediene, Algiers, Algeria

5 Université d'Alger 1, Algiers, Algeria 